\title{
RECREACIÓN GRÁFICA DE LA ICONOGRAFÍA INCA
}

Felipe Cortázar Velarde



RELIGIOSIDAD A $N$ D I N A

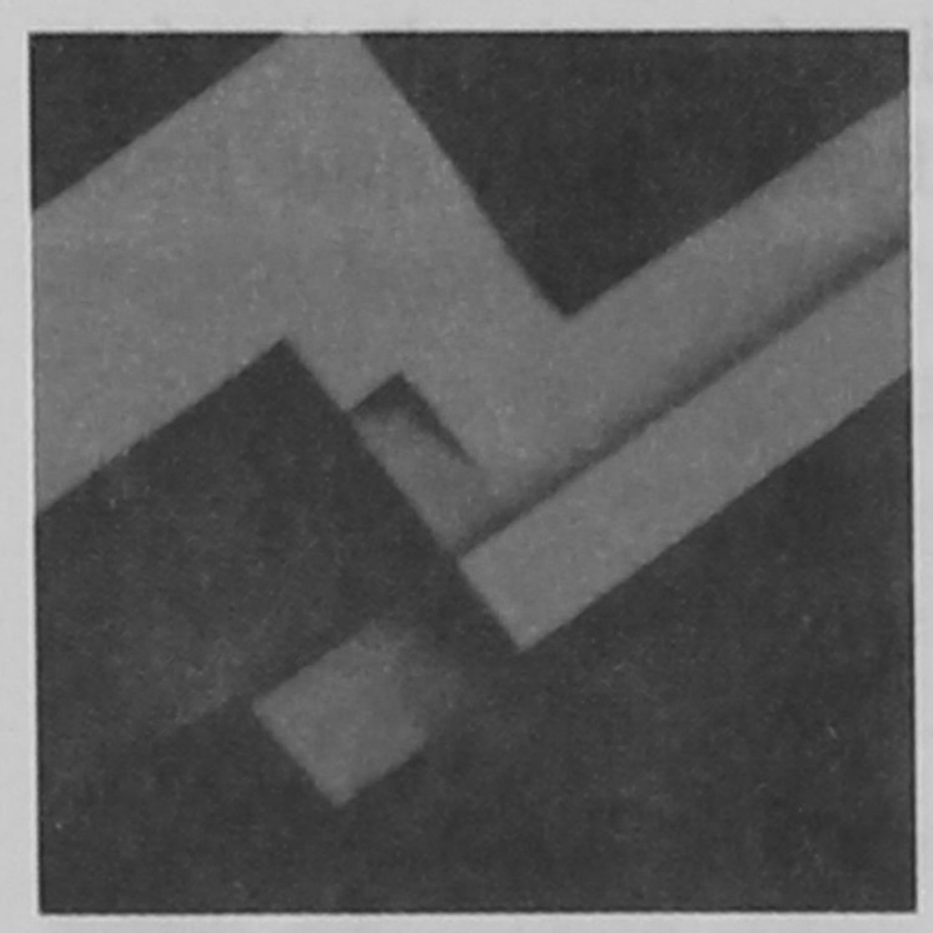

P O D E R Y AUTORIDAD EN LOS ANDES
La iconografía inca del Cusco ha sido la inspiración para la identidad gráfica de Allpanchis. Después de 18 años -al actualizarse el diseño de la revista-, es oportuno reflexionar acerca de ella y compartir el proceso de recreación que se alimenta de la identidad inca para volver a la actual, en función a un tema propuesto.

La propuesta de diseño - presentada en 1986 - propuso como tema gráfico central una viñeta con referencia en la iconografía inca del Cusco, debido a que Allpanchis es una revista vinculada a temas andinos y con sede en esa ciudad. Además, la intención fue explorar motivos incas en temas relacionados con la actualidad andina.

Esta propuesta no plantea una interpretación fundamentada estrictamente en la semiótica del diseño andino, sino más bien una reinterpretación de ésta. Y hacer, así, un vínculo de continuidad entre el diseño inca y el actual. Por ello, este proceso de búsqueda está más bien vinculado a actividades como la realizada durante la primera mitad del siglo 